\title{
The Private Sector in Argentina: A Limited and Selective Expansion
}

\author{
Marcelo Rabossi $\mathrm{i}^{\mathrm{a}, *}$ \\ ${ }^{a}$ Torcuato Di Tella University, Argentina
}

\begin{abstract}
The expansion of the private university market was part of a global trend that grew vigorously at the turn of the twenty first century. Although private demand has long dominated Southeast Asian countries, Latin America has also witnessed a dramatic shift toward non-public options since the early 1990s. However, not all countries in the region reacted alike, and Argentina can be an exception to this global private expansion. In fact, the State is still the dominant actor, fulfilling its role as the main demand-absorber of post-secondary students. In a market where the private sector was not always "welcomed," the objective is to study the development of the private university market in Argentina, paying special attention to the main particularities of this growth. This dynamic will be studied from an isomorphic approach to understand what have been the main consequences in terms of organizational forms and practices before a dominant and controlling State.
\end{abstract}

\begin{abstract}
Abstrak
Ekspansi pasar universitas swasta menjadi tren dunia yang tumbuh pesat di akhir abad 21. Selain mendominasi negara-negara Asia Tenggara, tren universitas swasta juga melanda Amerika Latin yang secara dramatis menjadikan institusi non-publik ini sebagai opsi pada awal 1990an. Namun, tidak semua negara di wilayah tersebut menunjukkan respon sama. Di Argentina misalnya, pemerintah masih menjadi aktor dominan, memegang perannya sebagai institusi utama yang menyerap calon mahasiswa. Dengan pasar swasta yang tidak selalu mendapat sambutan ini, kami berupaya menelaah tren universitas swasta di Argentina, khususnya mengenai karakter pertumbuhan institusi ini. Perkembangan ini dianalia dengan pendekatan isomorfik (isomorphic) untuk menyelidiki beberapa konsekuensi pokok dari pola dan praktek organisasi ketika peranan pemerintah masih dominan dan berkuasa penuh.
\end{abstract}

Key Words: Argentina, Higher Education, Private Sector, Coercive and Non-coercive Isomorphism, Accrediting Agencies

\section{Introduction}

The rapid expansion of the private market for higher education that began in the late 1980s in Latin America was part of a global trend to accommodate an increasing demand for post-secondary education within an exhausted public sector with increasingly limited funds and growing fiscal deficits. During the 1990's, this expansion recognized no geographical boundaries, taking place beyond any political-economic system and without respecting higher education traditions. Not only an increasing scarcity of public funds put governments' backs to the wall, but also dissatisfaction with the rigidities and inefficiencies of the public sector generated opportunities for alternative providers (Johnstone,

*Corresponding author. Address: Miñones 2177, Buenos Aires, 1428, Argentina. Email: mrabossi@utdt.edu.
Arora, and Experton 1998). Thus, private institutions flourished at the turn of the twenty-first century. This worldwide trend that has long dominated such countries as Japan, South Korea, and Taiwan, for example, consolidated in Latin America. Following the same pattern, the number of private higher education institutions skyrocketed in many countries in Central and Eastern Europe (Altbach 1999).

Two visible exceptions to this private expansion, at least in South America, were Uruguay and Argentina. Unsurprisingly, both countries were part of a small group that only allowed the opening of a private alternative very late in comparison to their neighboring countries (Argentina in 1959 and Uruguay in 1985). ${ }^{1}$ In both cases, the public sector, which was the main and ruling actor, decided to provide university education to almost everybody. 
The objective of this article is to study the expansion of the private university market in Argentina, paying special attention to the main characteristics of this growth. I will analyze the impact of a dominant public university and a controlling State and its consequences in terms of organizational forms and practices. In this work, the concept of dominance is the same as used in structural functionalism theory (Parsons 1951). People, or institutions, are ranked by others in terms of how well they perform according to certain dominant values accepted by society. When some roles are more respected than others, a social hierarchy that takes place within certain subgroups leads to social stratification, or in Argentina's case to a kind of organizational stratification. In Argentina, not only was the State historically the main provider for higher education, exercising a monopolistic position for more than 130 years (from 1821 to 1959), but also the elite of the system has been, and to some extent still is. In other words, the national university is at the top of the academic hierarchy. Thus, for some of the new private institutions it was a model worth being imitated.

The expansion of the private market of higher education around the world was, in many cases, an unanticipated phenomenon that took governments by surprise, where the state role in planning was limited (Levy 2006). It is expected that under such conditions, opportunities for low-quality institutions to flourish increase. Mexico and El Salvador are just two examples in Latin America where an absent state led to an explosion of "flyby-night" higher education institutions (Kent and Ramirez 1999). On the other hand, in Argentina, the opening of the private sector was from the very beginning a major public policy issue. The expansion never took the state by surprise. It could be said that private quality was a major public concern upon inception. In other words, the role of the State as a strict regulator was defined from the outset.

Under such dynamics, pay special attention is paid to private reactions before a public sector that has been always ready to put a stop to private growth, and also alert to disallowing low quality growth. Thus, I will focus on private higher education institutions' organizational change, triggered by local pressures and conditions. To analyze the private behavior under such rules, the New Institutionalism (NI) in organizations analysis (DiMaggio and Powel 1991) will be used. This approach provides a useful theoretical framework to analyze why, under certain conditions, a process of convergence makes organizations look more similar over time. This behavior can be voluntary (non-coercive), or externally induced by formal or informal pressure (coercive).

Although the use of this theoretical framework to explore dynamics in higher education is not new (Levy 1999; Vaira 2004), the contribution of this article lies in the fact that it considers the private university market under a dynamic approach. The article begins in 1959, the year when the first private university in Argentina opened its doors, until 2009, segmenting this 50 years span in three well defined periods. In a longitudinal study, I will try to show what kind of isomorphic force has impacted each period (coercive or non-coercive), what organizational models have been copied (public or private, local or foreign), and what were the main consequences in terms of organizational forms and practices.

\section{The Private University Market in Argentina: Birth and Evolution}

\section{Early and Unsuccessful Attempts}

In contrast to Brazil, Chile and Colombia (to name but three important systems in the region with regard to number of students), private higher education in Argentina got a late start. Early attempts to challenge the public monopoly, particularly during the first half of the twentieth century, faced strong state opposition. While public universities were reported as being a mere appendix of executive power, efforts to defy the single provider of university education surged, beginning in the late 1890s. As in the rest of the continent, the Catholic Church took the lead, opening the Catholic University of Buenos Aires in 1910. However, the institution never got State recognition and was forced to close its doors in 1922 (del Bello, Barky, and Giménez 2007). On the other hand, and since the mid-1940s, several attempts to limit the public domain emerged again. This time the effort came from the lay side, particularly from the scientific community. The idea was to build a private research sector to isolate the academic work of scientists from the political struggles that were taking place in the public university. However, the State succeeded again in defending its role as the only supplier of university education.

Looking at these first attempts for diversifying the market for higher education, Argentina resembles what was taking place in other main systems of Latin America, at least theoretically. This confirms, for the Argentine case, Levy's (1986) main findings about three main waves that explain private development in the region: church-elite-mass absorbing. ${ }^{2}$ However, contrary to what was happening in the rest of the region, neither the religious nor the elite option had a chance or was effective in challenging the public monopoly. On the one had, a strong anticlerical posture among some influential members of government hampered the consolidation of religious offers. On the other, and although public failures paved the way for an elite alternative, there was no room for any kind of private initiative. Under the concept of the 
Napoleonic model, where the university is seen as an essential institution to consolidate a national identity, any private option, religious or not, was perceived as a threat to the public interest. In such a particular environment, Argentina did not follow the general pattern of non-public expansion that was taking place in several countries in the region (e.g., Colombia, Chile, Mexico and Brazil).

\section{Birth, Early Development, and Decline}

However, the public monopoly would not last forever. After much debate, the 1958 law was passed authorizing the opening of the first private universities. As soon as these institutions got public recognition in 1959, the sector consolidated its presence. During this first wave, or early consolidation, the role played by Catholic institutions, in consonance with Levy's three waves model (1986), was fundamental to secure the private sector as a real alternative to a state monopoly that was held for almost 140 years (del Bello et al. 2007). Thus, by the end of the first decade of private development - the $1960 \mathrm{~s}$ - the country presented a vigorous and growing sector. Since the opening of the private sector was a major public policy issue upon inception, the expansion never took the state off-guard, as happened in many Latin American countries (e.g. Mexico, Brazil, and El Salvador). This was essential to keep quality under control. In other words, private growth in Argentina was limited and selective from the outset.

Notwithstanding, rapid expansion during the first decade was followed again by state resistance. As the public sector absorbed the bulk of the new demand, particularly during the early 1970s and again during the $1980 \mathrm{~s}$, no new private universities were legally allowed to open their doors during a span of 16 years (1973-1989). Under such restrictive policies, by the end of the 1980 s there were only 23 private universities. Also, the free-for-all and the no entry examination policy implemented in almost all public institutions were successful in channeling the bulk of new students into this sector.

Unsurprisingly, in comparison to its public counterpart, the private market presented an erratic expansion. After sustained growth during the $1960 \mathrm{~s}$, the student enrollment share reached 17.4 percent after the end of this decade. Then, the open admission policy implemented in 1974 resulted in the private market only capturing 11.6 percent of all university students by 1975 . A 19.3 percent share in 1983 was followed by 12.7 percent in 1985 when the open admission, free-for-all policy was implemented again in the whole public sector. The number of enrollees in private institutions decreased by 7.6 and 6.2 percent in 1985 and 1986, respectively. Thus, Argentina became one of the first Latin
American countries to face a decline in the number of private students. $^{3}$

\section{The 1990s and a New Opportunity}

However, the 1990s presented a new panorama for private interests. As the State again opened the doors for private ventures, the sector reacted vigorously. However, by keeping the free-for-all mechanism, the State was again the main absorber of new enrollees. Within such an environment, private growth became limited in terms of demand - in 2000, private enrollment reached 15.1 percent, 4 percentage points less than 1983 .

On the other hand, in terms of supply, the private sector showed its dynamism. By the mid 1990s, for the first time private institutions outnumbered public ones. Between 1989 and 1996 a total of 23 new private universities entered the market (Secretaría de Políticas Universitarias [SPU] 2008). However, this early expansion was rapidly followed by more public control. The creation of the National Commission for University Evaluation and Accreditation (CONEAU) strongly limited the growth of the private market once again. In terms of supply (i.e., number of universities), the private market showed its vigor, especially during the first half of the 1990s; in terms of demand the reaction was less convincing. Currently there are 60 private universities and 55 public institutions (Ministry of Education 2011). Figure 1 clearly shows the erratic and limited growth of private enrollment share, making it clear that the public sector was the main actor in charge of absorbing the growing demand for university education.

Figure 1. Private Enrollment Share in Argentina in the University Sector (1960-2008)

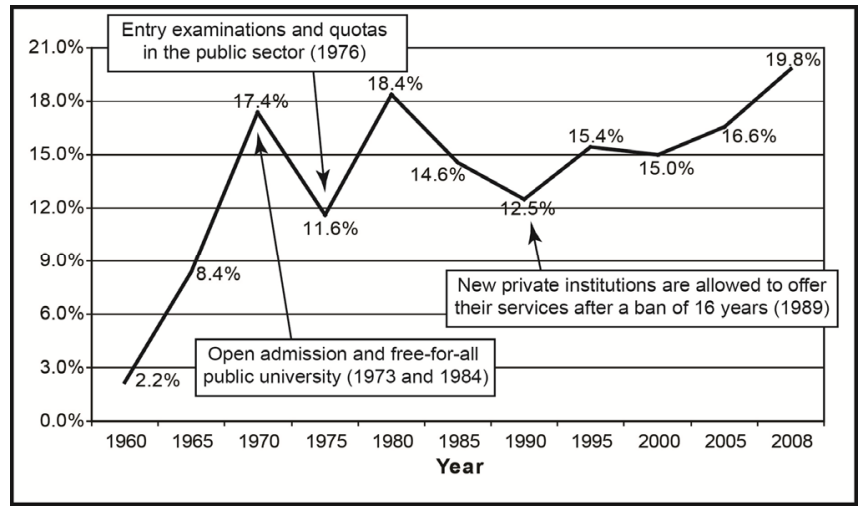

Source: Levy (1986), SPU (2008), and author's calculations.

With strong regulation from the outset, followed by more regulation, the private university sector did not have the opportunity to consolidate as an alternative with real impact. For 
example, the decrease in private relative enrollment in the mid1970s and again in 1980s shows how public decisions, in this case the implementation of an open admission, free-for-all public university, affected the consolidation of a non-public alternative. And although the opening of the market to new private alternatives in 1989 resulted in a relative increase in the percentage of students, this expansion was somewhat limited in comparison to what was taking place in Chile, Brazil, Peru or Colombia, just to name some countries where the private sector was the main actor in charge of absorbing the bulk of the new demand during the 1990s (García Guadilla 1998).

\section{A Limited and Selective Growth: An Isomorphic Approach}

Although one can speculate that under market competition an organization will try to differentiate from others, taking advantage of its own distinctiveness, it is also true that organizational forms and practices tend to look alike as a way of "securing" a position in society. This isomorphic behavior limits differentiation, where institutions in a market resemble other institutions that face a similar set of environmental conditions. According to DiMaggio and Powell (1991), institutions tend to behave in a routine, unreflective way leading to extensive copying. In a way, this mimetic, non-coercive isomorphic response is seen as an organizational reaction to limit uncertainty. By copying others that proved to be successful, institutions limit the risk of failure, particularly in the face of uncertain solutions. Also, dominant organizations set the patterns that new or less influential institutions seek to copy. In any case, all these practices are voluntary, where organizations respond to uncertainty. Specifically, there is no coercion here. On the other hand, organizational change can be the product of coercive actions, consequences of formal or informal pressure exercised on one organization by a ruling entity, for example. This latter must have the power, generally legal, upon which the former must obey. The legitimate structure could be the result of rules and standards defined by governmental regulations (Tolbert and Zucker 1983). A common legal environment can shape organizations in a similar way, limiting diversity. Under such restrictions, voluntary approaches are sometimes a way to reduce uncertainty, or legally imposed market competition that does not play a significant role in shaping an entity's structure.

During the early evolution period (1959-1972), private institutions in Argentina took their public counterparts as the model to be imitated, particularly Catholic universities, in what can be described as a non-coercive isomorphic attitude. The modernization of the public university that began during the late 1950 s and early 1960 s, when the national institution reached the peak of its splendor, was a model worth mimicking. Legitimacy is higher if institutions aspire to be serious; and public, during this period, was a synonym of seriousness. Non-Catholic private institutions during this period also saw in their public counterparts a model to follow. Thus, there was no major innovation or diversification. In addition to these, certain characteristics of the academic labor market have helped private universities to resemble public ones even more. Given that full-time faculty positions in both sectors are limited, most private institutions have recruited part of their personnel among professors working in their public counterparts. Consequently, a considerable number of faculty members developed their careers in both sectors. This feature accurately portraits a dynamic found in the main systems of higher education in the region (Bernasconi 2008). Given this situation, no major inter-sectoral distinction in the academic labor market was found.

On the other hand, the law that authorized the opening of private institutions only allowed the creation of non-for-profit universities. Thus, in terms of financial differentiation, at least in what relates to the distribution of monetary benefits, intra- and inter-sectoral distinction is also limited. In sum, restricted diversity during the first expansion was mainly a direct response to noncoercive forces, where private pretended to be "public," and a coercive policy, where the State was successful in limiting differentiation. ${ }^{4}$

The 1990s gave private institutions a new chance to expand their offer. Under a favorable state policy that fostered new private ventures, this period was characterized by a more heterogeneous private supply. The main idea was not necessarily to mimic the public sector to get recognition, as was the case during the early stages of development. In terms of expansion, this second private wave (1989-2008) can be divided into two main sub-periods. In the first one (1989-1995), private institutions grew with conviction, surpassing for the first time the number of public universities. Not accidentally, this period coincides with a promarket reform centrally determined from the Ministry of Education. The objective was to foster competition among higher education institutions. This policy took part within a general context of a macro neo-liberal restructuring that was intended to promote the logic of the "invisible hand" in the whole economy. Within a "friendly" environment, 23 new private universities opened their doors during this sub-period (Ministry of Education 2011). Entrepreneurs, foundations, and even some secondary schools that were waiting to expand academic offerings saw this time as a real opportunity. With a growing private supply generating a new demand, private enrollment showed some vigor.

On average, the market witnessed the appearance of good academic quality projects, within a mix of elite and some serious 
demand-absorbing institutions, although these latter institutions did not find enough room for developing a subsystem with a clear impact. Specifically, there were no conditions for the development of a real demand-absorbing subsystem as happened in some Latin American countries (Brazil and Colombia, for example). In Argentina, this role was reserved for the State. On the other hand, and although enrolling no more than 5 percent of the whole private market, a group of elite universities emerged to give response to a demand, which was unsatisfied with the traditional model of education. This group was able to emulate from the outset some characteristics that were generally found in the US research model. By imitating US patterns (the elite US sector in particular), research activity and full-time contracts, although not necessarily dominant, are now present at these institutions, at least in their organizational wishes and academic aspirations. Again, as in the early evolution period, a process of non-coercive isomorphism defined the shape of these new universities. But this time the model to be emulated was not local but foreign. In order to legitimate their international condition and academic seriousness even more, some of these institutions repatriated young researchers that were working at some European and US universities. Part of the faculty body was not recruited from the public sector, but from abroad.

On the other hand, the second sub-period (1996-2008), was one where the expansion of the private market found a ceiling, at least in terms of supply. The years when the legal requirement to open a new private institution appeared to be less strict (1989-1995) came to an end. ${ }^{5}$ It happens that with greater freedom came greater supervision with the objective of controlling the quality of education. In 1996, the opening of the accrediting agency (CONEAU) played a major role in shaping the new structure of the market. Levy (2006) observes that after being taken by surprise, states reacted through delayed regulation to limit private growth, or at least to prevent low quality growth. It must be taken into account that the increasing number of private Latin American universities by the end of the 20th century added a broad heterogeneity in terms of quality and resources. The influence of the North American model of higher education resulted in the introduction of evaluation and accreditation procedures to keep quality under control (Gonzáles 1999).

The CONEAU in Argentina played a decisive role during the long accreditation process all private universities were required to pass. From the very beginning, conditions for "aspiring-to-be" universities were strict. Membership, so to speak, is exclusive. It is not surprising that from its creation to 2009, out of 106 accreditation requests only 12 institutions were allowed by CONEAU to function as authorized universities (CONEAU 2008). By limiting the ports of entry, the agency allowed scarce opportunity for "fly-by-night" private institutions of the sort rampant in much of Latin America, limiting again the expansion of a private demand-absorbing subsector. This strict legal environment exerted on the private market an obvious pressure. It could be said that organizational change during this second subperiod of private expansion was clearly influenced by government mandate.

\section{The Health Subsector: An Example of Coercive Isomorphic Reaction}

It is commonly know that private universities tended to specialize in social sciences and humanities. Cost and the lack of a real demand are two main factors that certainly prevent private institutions from expanding their offerings beyond less costly fields. Also, studies of Latin America have established that relative to public institutions, the private sector concentrates in the social sciences and humanities, where the cost of provision is less expensive (Levy 1986; de Moura Castro and Navarro 1999; CINDA 2007). However, Argentina presents a case where a strict legal environment paved the way for the development of an atypical private sector. Within a restrictive legal environment, medical schools were more apt at responding to the new legislation imposed by CONEAU. Organizational change here is a direct response to government mandate. Then, a coercive isomorphic behavior helped non-public institutions to resemble their public counterparts, at least in terms of field specialization. Almost 60 percent of the new private institutions created after 1996 offer careers in health sciences (7 of 13), and five of them opened their doors as Health University Institutes. Within this dynamic, the appearance of a strong private health subsector should not be surprising.

Figure 2 shows the evolution of enrollment in the private university sector in Argentina in terms of fields of study. In quantitative terms, and between 1996 and 2008, health sciences absorbed part of the private demand to the detriment of social sciences careers, although the proportion of enrollees in the latter still dominates.

By analyzing the distribution of students in both areas of study, it was found that, while in 1996 relative enrollment in social and health sciences reached 65 percent and 3 percent, respectively (the remaining 32 percent were distributed among humanities, applied, and basic sciences), in 2008, students in the social sciences decreased to 56 percent, with a health subsector absorbing 11.9 percent of all university enrollees. Thus, the increase of the health subsector to the detriment of the social sciences clearly shows the impact that CONEAU exercised over the sector. 
Figure 2. Student Enrollment in Private Universities in Argentina Share by Field of Study (1996-2008)

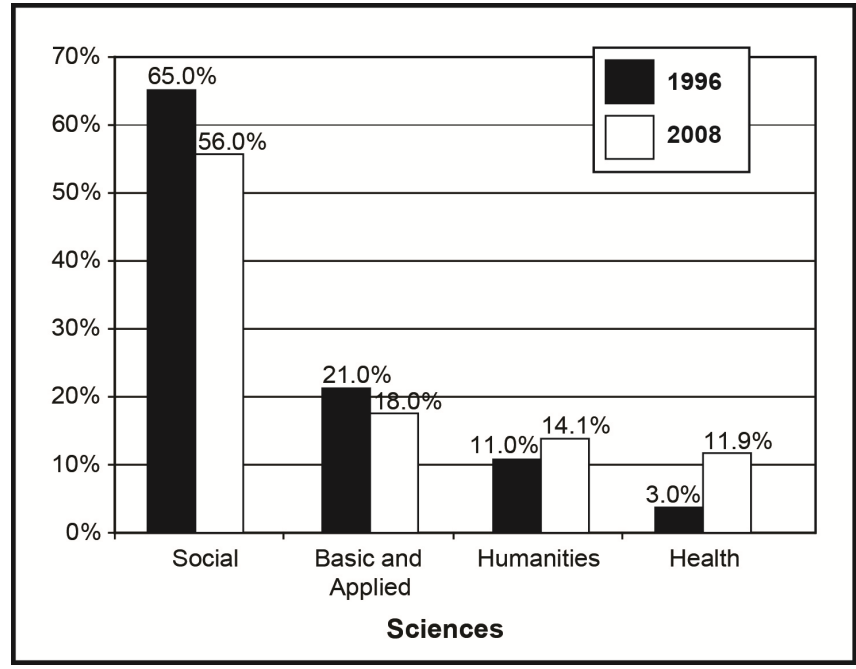

Source: SPU (2008) and author's calculations.

However, beyond public intervention (a coercive isomorphic policy), several factors also fostered this kind of atypical growth. First, "public failures" can offer an opportunity for private expansion (Levy 1986). For example, in comparison to public schools of medicine, private schools in general are more efficient, allowing students to finish their studies in a shorter time period. ${ }^{6}$ Second, intense politicization inside the University of Buenos Aires (an institution that enrolls almost half of all medicine students) "forced" upper-middle class students and families to seek new alternatives. In addition to this, and although the public system offers an open admission policy, some public schools of medicine have established entry examinations. Thus, these perceive public failures together with some entry restrictions, on the public side, offered private universities an opportunity to expand beyond their traditional niches (Rabossi 2011).

\section{Conclusion}

The private university market in Argentina has shown a limited and erratic expansion during its first five decades of creation, expansion and development (1959-2009). With a vigorous Catholic sector taking the lead, the State was ready to set up effective entry barriers that prevented more dynamic growth. A governmental decree issued by the Peronist government (1973-76) prohibiting the creation of new private universities is just one example of a policy that never fostered non-public options. In addition, the open admission system implemented in all public institutions between 1973 and 1976, and again since 1984, was effective in channeling part of the private demand to public settings. And although in 1989 private ventures found a new opportunity to expand, since 1996, CONEAU was decisive in allowing only selective private growth. Consequently, the lack of a private demand-absorbing subsystem that characterized most of the expansion in Latin American should not be surprising.

Within a highly regulated scenario, private universities in Argentina developed their own formal structures, sometimes mimicking the public sector and other times copying other private institutions. Organizations tend to model their formal structure after other entities, where uncertainty is a powerful force that promotes imitation (Powell and DiMaggio 1991). The model to be imitated can be local or foreign, but it is one that organizations perceive that is socially recognized. The entity to be copied is one that has proven to be successful and that has been socially legitimized.

During the first private expansion, the public national system was the model to follow, and especially the UBA, the most prestigious institution in the country. Thus, the UBA can be seen as a case, or the entity, that limited the space for private growth, or at least a more heterogeneous growth. Since 1989, when the second private expansion began, and when an exhausted and underfunded national university presented more doubts than certainties in terms of academic quality and innovation, some new private institutions started to look abroad. For a handful of elite private universities the model was foreign. However, it is worth highlighting that the mimetic process that developed during the 1990s went beyond private realities. Some new public universities, particularly those created after 1989, also began to build their formal structure after non-local models. Administration boards with less student representation, and departmental design instead of the classic chair model, demonstrate that some new public institutions also found their inspiration in foreign designs, particularly the US design. It must be taken into account that the chair system is the model that historically has defined how faculty members are distributed within ranks in the Latin American university (Bernasconi 2008). Thus, such behavior shows that in terms of its organizational forms and practices, and particularly in what is related to the decision making process at the faculty level, public-private differentiation also tended to blur.

On the other hand, the process of transformation that began in the private sector during the 1990s shows that organizations tend to copy what is successful today, independently of the sector to be emulated. The dominant role, non-coercively speaking, can be either in private or public hands. Structural changes happen when new organizational technologies are demonstrated to be more successful than older ones. Differentiation only arrives when the model that was formerly copied proves its obsolescence. The 
classic bureaucratic model represented by the UBA that was strongly copied during the first period began to show its limitations at the end of the 1980s. Subsequently, both private and the new public institutions began to look abroad. Thus, no single pattern of copying in the university market in Argentina was found. Sometimes private universities emulated other private or public institutions, and vice versa. On the other hand, when coercive isomorphic forces limited the private expansion once again (1996-2009), only those institutions that were well aligned to the requirements of the new accountability movement imposed by CONEAU were able to succeed. As a result, it is not surprising that the private health sub-sector expands relatively more than other traditional private fields. Supported by well-known scientists and working in conjunction with well-respected private hospitals, these new university institutes were able to rapidly align to the regulatory requirements imposed by the quality assurance movement (Rabossi 2011).

Table 1 shows the evolution of the private university sector in Argentina in terms of the isomorphic type that influenced the expansion, and the dominant force behind this behavior.

Table 1. The Private University Sector and the Isomorphic Process

\begin{tabular}{lll}
\hline Period & Isomorphic Type & Main Influence \\
\hline $\begin{array}{l}\text { Early Evolution } \\
(1960-1973)\end{array}$ & Non-coercive & Local public institutions \\
$\begin{array}{l}\text { Second Expansion } \\
(1989-1995)\end{array}$ & Non-coercive & Foreign private institutions \\
$\begin{array}{l}\text { Regulated Growth } \\
(1996-2009)\end{array}$ & Coercive & $\begin{array}{l}\text { National accreditation } \\
\text { agency }\end{array}$ \\
\hline
\end{tabular}

As a practical way of summarizing the findings, highlighted below are the main aspects that described each period. During the early evolution (1960-73), it was found:

- Private institutions taking their public counterparts as the model to be imitated, particularly Catholic universities, in what can be described as a non-coercive isomorphic attitude.

- The modernization of the public university began during the late 1950s and early 1960s, a time when the national institution reached the peak of its splendor and was a model worth mimicking.

- Non-Catholic private institutions during the period followed the same trend. There was no major innovation or diversification.

- To gain in legitimacy, most private institutions recruited part of their personnel among professors who also work in the public sector.
The main characteristics of the second expansion (1989-1995) were:

- A more heterogeneous private supply, within a mix of elite and some serious demand-absorbing institutions.

- With an exhausted and underfunded national university, some new private institutions began to look abroad to find a model worth imitating.

- Some new small private universities began to emulate the US research university model.

- In order to legitimate their international condition and academic seriousness even more, some of these institutions repatriated young researchers who were working at some European and US universities.

From 1996 to 2009 (regulated growth), it was observed that:

- The creation of the CONEAU (1996) played a major role in shaping the new structure of the market.

- Out of 106 accreditation requests, only 12 universities were allowed by the Agency to function as authorized universities.

- Argentina presents a case where a strict legal environment paved the way for the development of an atypical private sector (in this case health).

- Within a restricted and restrictive legal environment, medical schools were more apt at responding to the new legislation imposed by CONEAU.

However, it must be said again that in important aspects, public control in Argentina was rigorous from the outset, even before the appearance of CONEAU. Strict action avoided the creation of mediocre private universities as happened in many countries in the region. The fact that CONEAU did not close down any private university, as happened in El Salvador and Mexico (Elías Campos 2004), for example, confirmed that since the early evolution period, the Ministry of Education was very active in limiting low quality growth. Public restriction, ideologically supported first and then regulation driven, can explain why private growth and diversification in Argentina was far from reaching the levels that are generally found in other countries in Latin America.

\section{Notes}

1. In comparison to Colombia, Chile, Peru and Brazil, as four of the most important systems in terms of student enrollment, the 
opening of the first private university preceded Argentina by 73 , 71,42 and 19 years respectively (Levy 1986).

2. According to Levy (1986), the growth of the private university sector in Latin America occurred in three consecutives waves. The first one, the Catholic Reaction, depicted the role played by the Church in the creation of the first private institutions in the region. The second growth option, the Elite, basically a secular phenomenon, is the reaction of a social group who saw their privileges in jeopardy by sharing their interests with lower classes in a politicized public university. The third and last wave, Nonelite Private Alternatives, describes the secular private development to give an answer to the failure of the public sector.

3. While private enrollment share was declining in Argentina during the 1980s, in the main countries of the region the tendency was the opposite. For example, at the end of this decade, more than half of all post-secondary students in Brazil and Colombia were enrolled in private institutions; enrolment was around 30 percent in Chile and Peru (García Guadilla 1998).

4. According to Levy (1999), another aspect that inhibits the diversification of the private market in Argentina is the role played by public institutions, and particularly the University of Buenos Aires (UBA). In contrast to state coercion, societal corporatism constrains distinctiveness through diversification. Enrolling more than 300,000 students, UBA is still considered the most prestigious institution in the country.

5. It is fair to say that public control through the Ministry for Education avoided the creation of mediocre private universities, particularly if mediocre refers to "garage institutions."

6. Private institutions, in comparison to their public counterparts, are more internally efficient. Consequently, graduation rates are higher, for example. However, I am not suggesting that graduates from private universities are better than graduates from public universities.

\section{References}

Altbach, Philip G. 1999. "Private Higher Education: Themes and Variations in Comparative Perspective." In Private Prometheus: Private Higher Education and Development in the 21st Century, ed. Philip G. Altbach (pp.1-15). Chestnut Hill, MA: Center for International Higher Education, School of Education, Boston College.

Bernasconi, Andrés. 2008. "Is there a Latin American Model of the University?" Comparative Education Review 52 (1): 27-52.

Centro Interuniversitario de Desarrollo (CINDA). 2007. Educación Superior en Iberoamérica: Informe 2007. Santiago de Chile: CINDA.
Comisión Nacional de Evaluación y Acreditación Universitaria (CONEAU). 2008. Memoria Anual 2008. Buenos Aires: CONEAU. Available online at: http://www.coneau.gob.ar.

de Moura Castro, Claudio, and Juan Carols Navarro. 1999. "Will the Invisible Hand fix Latin America Private Higher Education?" In Private Prometheus: Private Higher Education and Development in the 21st Century, ed. Philip G. Altbach (pp.45-64). Chestnut Hill, MA: Center for International Higher Education, School of Education, Boston College.

del Bello, Juan Carlo, Osvaldo Barky, and Graciela Giménez. 2007. La Universidad Privada Argentina. Buenos Aires: Libros del Zorzal.

DiMaggio, Paul J., and Walter W. Powell. 1991. "The Iron Cage Revisited: Institutional Isomorphism and Collective Rationality in Organizational Fields." In The New Institutionalism in Organizational Analysis, ed. Walter Powell and Paul DiMaggio. Chicago: University of Chicago Press.

Elías Campos, Adalberto. 2004. "Educación Superior Privada Universitaria en El Salvador." Study for IESALC-UNESCO. Available online at: http://proyecto.unlam.edu.ar.

García Guadilla, Carmen. 1998. Situación y Principales Dinámicas de Transformación de la Educación Superior en América Latina. Caracas: IESALC-UNESCO.

Gonzáles, Luis. 1999. “Accreditation of Higher Education in Chile and Latin America." In Private Prometheus: Private Higher Education and Development in the 21st Century, ed. Philip G. Altbach (pp.65-84). Chestnut Hill, MA: Center for International Higher Education, School of Education, Boston College.

Johnstone, Bruce, Alka Arora, and William Experton. 1998. "The Financing and Management of Higher Education: A Status Report on Worldwide Reforms." Working Paper. Washington, DC: The World Bank.

Kent, Rollin, and Rosalba Ramírez. 1999. "Private Higher Education in Mexico in the 1990s: Growth and Differentation." In Private Prometheus: Private Higher Education and Development in the 21st Century, ed. Philip G. Altbach (pp. 85100). Chestnut Hill, MA: Center for International Higher Education, School of Education, Boston College.

Levy, Daniel. 1986. Higher Education and the State in Latin America: Private Challenges to Public Dominance. Chicago: University of Chicago Press.

Levy, Daniel. 1999. "When Private Higher Education Does Not Bring Organizational Diversity." In Private Prometheus: Private Higher Education and Development in the 21st Century, ed. Philip G. Altbach (pp. 15-44). Chestnut Hill, MA: Center for International Higher Education, School of Education, Boston College. 
Levy, Daniel. 2006. "The Unanticipated Explosion: Private Higher Education's Global Surge." Comparative Education Review 50 (2): 217-240.

Ministry of Education. 2011. Sistema Universitario. Buenos Aires, Argentina: Ministry of Education. Available online at: http://portal.educacion.gov.ar.

Parsons, Talcott. 1951. The Social System. London: Routledge.

Rabossi, Marcelo. 2011. "Differences Between Public and Private Universities' Fields of Study in Argentina." Higher Education Management and Policy 23 (1): 1-20.

Secretaría de Políticas Universitarias (SPU). 2008. Anuario 2008 de Estadísticas Universitarias. Buenos Aires, Argentina: SPU. Available online at: http://portal.educacion.gov.ar.

Tolbert, Pamela S., and Lynne G. Zucker. 1983. "Institutional Sources of Change in the Formal Structure of Organizations: The Diffusion of Civil Service Reform, 1880-1935." Administrative Science Quarterly 28 (1): 22-39.

Vaira, Massimiliano. 2004. "Globalization and Higher Education Organizational Change: A Framework for Analysis." Higher Education 48 (4): 483-510. 